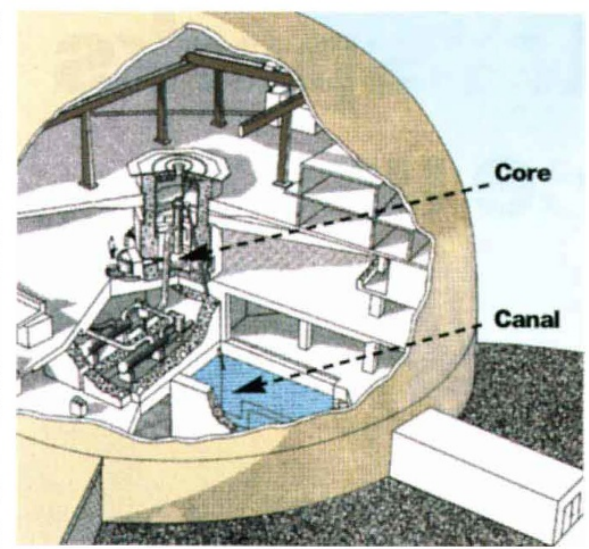

The 'canal' or spent fuel pool, on the lower level of the HFBR, is the suspected source of the leak.

efforts to reassure Long Island residents of the laboratory's safety (see Nature 384, 205; 1996) have been undermined. People who had come to accept the laboratory's good faith now feel let down, Casey says. "There's a high degree of outrage," he says. "It will be quite an effort for us to recover."

John Axe, head of science programmes at the HFBR, says that his staff will now be "out scrambling with the rest of our users" looking for access to other neutron sources. He admits that the closure will put some of the facility's 300 users in "a terrible situation".

The most directly comparable facility, at the National Institute of Standards and Technology, can - like Brookhaven - offer both thermal and cold neutrons. "I'll do everything I can," promises Mike Rowe, head of that facility. "The problem is I am already full. I'll end up cutting everybody back so that no-one gets cut out."

Thermal neutrons are available at the High Flux Isotope Laboratory at Oak Ridge National Laboratory in Tennessee. "Neutron sources worldwide are oversubscribed," says Bill Appleton, associate director of Oak Ridge. "We'll just have to stretch everybody out. It's not a pretty situation, but one we'll try to make the best of."

Overseas researchers use HFBR too. Jeremy Bradshaw, a biophysicist at the University of Edinburgh, had been planning to spend three weeks there this summer studying how a feline leukaemia virus attaches itself to cell membranes. He says he cannot use the Institut Laue-Langevin in Grenoble, France, because less time has been allocated to British scientists there, and he may use a facility in Berlin. "I think I'll be able to continue with my work, but clearly at a reduced rate," he says.

BNL's director, Nick Samios, says he is confident that the leak will be plugged and the facility reopened. Of energy department criticism, he says: "They said we should have moved a little faster - but we've been working very fast on a lot of things." BNL's strategy, he says, was to study ground water at the boundary and at old industrial waste dumps on the site first.

ColinMacilwain

\title{
British universities face up to their day of reckoning
}

[LONDON] A mixture of delight and despair was to be found in British universities last week as each received official notification of how their recent research performance has been used to decide their core funding from central government next year.

Some institutions were celebrating the successful outcome of many hours of careful preparation of submissions for the latest four-yearly research assessment exercise, carried out by the funding councils which distribute money to universities in England, Scotland and Wales respectively (see Nature 385, 3; 1997).

University College London, for example, a high number of whose departments were awarded a 5 or a $5^{*}$ in the exercise - indicating research at an international level of excellence - has been rewarded with a 9.5 per cent increase in its grant next year from the Higher Education Funding Council for England (HEFCE).

Much of this increase was the result of a growth of 23 per cent in the money allocated for the support of research. The University of Oxford, which performed best of all British universities in the exercise, with 75 per cent of its 'research active staff' considered to be in $5^{*}$ departments, will similarly see its overall grant rise by 7.5 per cent.

In contrast, the University of Cambridge will receive only 4 per cent more. University officials say that this reflects the fact that, although a greater proportion of its research staff was submitted for assessment than Oxford, one result was to reduce the level of gradings achieved.

Some of the so-called new universities, created out of polytechnics in the early 1990s, have also done well. Nottingham Trent University - formerly Trent Polytechnic - which raised the research performance of many departments from a 2 to a $3 a$ or $3 b$ (on a scale of 1 to $5^{\star}$ ), will have its funding for research increased by 74 per cent.

But the limited funding available inevitably means there have also been casualties. Some are large universities with established research reputations, in which a drop of one category in a large department - say from a 5 to a 4 - has been sufficient to trigger a substantial decline in overall research funding.

The University of Manchester, for example, has seen its allocation for research fall significantly - largely due to a fall in its ratings in some areas of medical research and has ended up with a budget reduction of 0.1 per cent this year.

Manchester and other universities would have experienced even heavier cuts if it were not for a 'moderation factor' introduced to mitigate the inevitable pain and disruption caused by a formula designed to reduce funding for poorly performing institutions.

The HEFCE announced that it was taking $£ 12$ million off the money that would have been allocated to top performing universities, and redistributing it to those at the bottom of the scale.

The result is that no university has seen its total grants reduced by more than 1.2 per cent. But it also means that some of the more successful institutions have seen their grants considerably reduced from what they would have been based on the funding formula alone - in the case of University College London, by $£ 1.7$ million.

Brian Fender, the director of HEFCE, defends the arrangement as a way of avoiding excessive financial stress on certain institutions. But he emphasizes that the safety-net procedure is likely to end next year, while those institutions that have required such assistance are being asked to draw up recovery plans.

The funding council's efforts at increased selectivity have been generally welcomed at a time when increasing student demand and level budgets are placing continuing pressure on higher education. "Spreading the misery evenly is not an option," says Gareth Roberts, vice-chancellor of the University Sheffield and chairman of the Committee of Vice-Chancellors and Principals.

The Association of University Teachers (AUT) is calling for extra money for universities - unlikely under even a Labour government - and is also asking for more weight to be given to the regional roles of universities in assessing their grants.

At present, the main criterion used, in addition to student numbers, is the quality of research. But the AUT points out that among the losers this year have been several institutions, such as the University of Exeter, University of East Anglia, and University of Hull, that are the only research institution in their geographical area.

Another group of losers has been some specialist research centres, such as the School of Pharmacy in London. "Too little attention has been given to protecting regional research centres or specialist institutions across England," says David Triesman, AUT general secretary.

HEFCE is already drawing up suggestions for ways in which such factors might be taken into account in future. Also included maybe consideration of the extent to which a university department has adopted priorities in line with the government's Technology Foresight exercise.

DavidDickson 